DOI 10.14746/ps.2016.1.30

\title{
Sprawozdanie z posiedzenia Rady Bezpieczeństwa ONZ nr 7498 na temat powołania międzynarodowego trybunału ds. katastrofy malezyjskiego samolotu, lot nr MH-17, Nowy Jork, 29 lipca 2015 r.
}

29 lipca 2015 r. w siedzibie Narodów Zjednoczonych (NZ) w Nowym Jorku odbyło się posiedzenie Rady Bezpieczeństwa (RB) w odpowiedzi na list z 28 lutego 2015 r. wystosowany przez Yuriya Sergeyeva, Stałego Przedstawiciela Ukrainy przy Narodach Zjednoczonych, do Przewodniczącego Rady Bezpieczeństwa NZ.

Celem spotkania było przyjęcie rezolucji powołującej Międzynarodowy Trybunał Karny w sprawie katastrofy malezyjskiego Boeinga 777. Samolot należacy do przewoźnika Malaysia Airlines i wykonujący lot nr MH-17 z Amsterdamu do Kuala Lumpur został zestrzelony nad terytorium Ukrainy (obwód doniecki) w dniu 17 lipca 2014 r. Na pokładzie maszyny znajdowało się 283 pasażerów z 10 państw, w tym 15 członków załogi. Wszyscy ponieśli śmierć na miejscul ${ }^{1}$.

Autorami projektu rezolucji było 19 państw: Australia, Belgia, Kanada, Francja, Niemcy, Indonezja, Irlandia, Izrael, Włochy, Litwa, Malezja, Holandia, Nowa Zelandia, Filipiny, Rumunia, Hiszpania, Ukraina, Wielka Brytania i Stany Zjednoczone. W spotkaniu wzięło udział 15 członków Rady Bezpieczeństwa ${ }^{2}$, a także przedstawiciele Australii, Belgii, Kanady, Niemiec, Irlandii, Izraela, Włoch, Holandii, Filipin, Rumunii, Ukrainy i Wietnamu.

Obradom przewodniczył Murray McCully, Minister Spraw Zagranicznych Nowej Zelandii ${ }^{3}$, który rozpoczął je minutą ciszy dla uczczenia pamięci ofiar tragicznego lotu. $\mathrm{Na}$ wstępie podziękował również za przybycie ministrom z Australii, Holandii, Malezji i Ukrainy, dodając, że ich obecność potwierdza wagę omawianego problemu.

Jako pierwszy głos zabrał Liow Tiong Lai, Minister Transportu Malezji, który przedstawił treść projektu rezolucji o ustanowienie międzynarodowego trybunału w sprawie lotu MH-17. Przemówienie wygłosił w imieniu zespołu dochodzeniowego ds. zbadania przyczyn katastrofy, zlożonego z ekspertów z Australii, Belgii, Malezji, Holandii i Ukrainy. W swoim wystąpieniu podkreślił, że przyjęcie tej rezolucji ma kluczowe znaczenie dla bezpieczeństwa lotnictwa cywilnego w przyszłości i pozwoli na rozszerzenie współpracy w prowadzeniu dochodzenia o kolejne państwa i podmioty w regionie. Dodal, że pomimo trwającego już śledztwa Holenderskiej Rady Bezpieczeństwa również i RB NZ powinna wykazać się odpowiedzialnością oraz zaangażowaniem w zbadanie tej tragedii. Przypomniał, że może ona skorzystać z uprawnień nadanych jej w rozdziale VII Karty Narodów

${ }^{1}$ MH17 Malaysia plane crash: What we know, http://www.bbc.com/news/world-europe-28357880 (11.01.2015).

2 W lipcu 2015 r. w skład Rady Bezpieczeństwa wchodzily następujące państwa: Angola, Czad, Chile, ChRL, Francja, Jordania, Litwa, Malezja, Nigeria, Nowa Zelandia, Rosja, Hiszpania, Wielka Brytania, Stany Zjednoczone, Wenezuela.

3 Nowa Zelandia sprawowala przewodnictwo w Radzie Bezpieczeństwa w lipcu 2015 r. 
Zjednoczonych. Minister Lai w swoim przemówieniu odwołał się również do rezolucji RB nr 2166 z 2014 r., w której wszyscy jej członkowie jednogłośnie opowiedzieli się za przeprowadzeniem niezależnego śledztwa i pociagnięciem do odpowiedzialności winnych zbrodni. Podkreślił, że ustanowienie trybunału daje z kolei gwarancję pełnej apolityczności takiego dochodzenia. Na zakończenie przemówienia wezwal wszystkich członków Rady do wykazania się sprawiedliwością w stosunku do rodzin ofiar, a także przekazania jasnego komunikatu do rosnącej liczby zaniepokojonych podmiotów niepaństwowych, że nie ma zgody społeczności międzynarodowej na takie haniebne działania w przyszłości.

Po tym wystapieniu od razu przystapiono do głosowania nad projektem rezolucji. Za jego przyjęciem opowiedziało się 11 państw, 3 wstrzymały się od głosu (Angola, ChRL, Wenezuela), a Rosja zastosowała prawo weta. W związku z powyższym pomimo uzyskania większości głosów uchwała została odrzucona ze względu na brak wymaganego poparcia ze strony wszystkich stałych członków Rady.

W odpowiedzi na wynik głosowania Minister Lai wyraził głębokie ubolewanie nad odrzuceniem projektu. Dodał, że przy jego tworzeniu podjęto wszelkie wysiłki na rzecz zniwelowania różnic zdań pomiędzy państwami, a Malezja do końca wierzyła w ustanowienie międzynarodowego mechanizmu sprawiedliwości. Podkreślił, że mimo wszystko jego państwo nie zamierza wycofać się z dalszego śledztwa w tej sprawie, a także stanowczo potępił bezczynność Rady, której postawa nie ułatwiła rozwiązania problemu.

Jako kolejny głos zabrał przedstawiciel Rosji Vitaly Churkin. Swoje przemówienie rozpocząl od złożenia kondolencji rodzinom ofiar katastrofy, a następnie zaznaczył, że Rosja zrobiła wszystko, co było w jej mocy, aby zapewnić szybkie przyjęcie rezolucji RB nr 2166 z 2014 r. oraz przeprowadzić niezależne śledztwo. Stwierdził jednak, że pozostałe państwa zdecydowały się porozumiewać poza RB za pośrednictwem dwustronnych kontaktów z Ukraina. Przypomniał również, że rosyjscy eksperci przekazali holenderskim śledczym wszystkie dane potrzebne w procesie dochodzenia, w tym dane satelitarne, nie otrzymując w zamian równego dostępu do informacji. Podał przy tym w watpliwość bezstronność i dokładność prowadzonego dochodzenia ze względu na jego zamknięty charakter. Zaznaczył ponadto, że Rosja nie tylko przygotowała alternatywną rezolucję dla właśnie odrzuconej, ale także złożyła wniosek o powołanie Specjalnego Przedstawiciela Sekretarza Generalnego ds. zbadania przyczyn katastrofy Boeinga 777, który to wniosek został jednak odrzucony. W dalszym uzasadnieniu weta powiedzial, że Rosja nie poparła ustanowienia międzynarodowego trybunahu w oparciu o rozdział VII Karty NZ, ponieważ w rezolucji przyjętej przez RB w 2014 r. zestrzelenie malezyjskiego samolotu nie zostało uznane za zagrożenie dla międzynarodowego pokoju i bezpieczeństwa. Dodał też, że powołanie takiego trybunału niesie ze sobą olbrzymie koszty, czego przykładem jest Międzynarodowy Trybunał Karny dla byłej Jugosławii. Przypomniał, że kiedy Ukraina strąciła samolot rosyjski, a Stany Zjednoczone irański, nie powołano w tych sprawach międzynarodowego trybunału. Zauważył ponadto, że w przypadku problemu piractwa, które realnie zagraża międzynarodowemu bezpieczeństwu, idea trybunału nie cieszy się poparciem Rady. Stwierdził także, że przedłożenie projektu rezolucji do głosowania mimo świadomości pozostałych państw, że nie zostanie on przyjęty, wyraźnie uwidacznia motywy polityczne, jakimi kierowali się jego autorzy. Na zakończenie dodał, że brak poparcia ze strony Rosji dla utworzenia międzynarodowego trybunału w tej sprawie nie jest wyrazem promowania przez nią bezkarności.

Głos w debacie zabrała następnie Samantha Power, Stała Przedstawiciel USA przy NZ. $\mathrm{Na}$ początku wystapienia wyraziła ubolewanie nad śmiercią pasażerów lotu MH-17 
i dodała, że wśród ofiar katastrofy byli także obywatele USA. W dalszej kolejności wyraziła pełne poparcie USA dla ustanowienia międzynarodowego trybunału i dodała, że sprawcy tej tragedii muszą zostać bezwzględnie ujawnieni i ukarani. Potępiła ponadto nie tylko zastosowanie przez Rosję weta, ale również utrudnianie dostępu do miejsca katastrofy przez prorosyjskich separatystów. Podkreśliła, że dzisiejsza postawa Rosji jest oznaką lekceważenia przez nią protestów społeczności międzynarodowej, w tym także rodzin ofiar, które szczególnie zasługują na sprawiedliwe dochodzenie w sprawie malezyjskiego Boeinga.

Kolejnym przemawiającym był Bert Koenders, Minister Spraw Zagranicznych Holandii. Na początku zaznaczyl, że jego państwo zostało szczególnie dotknięte tą tragedia, ponieważ wśród blisko 300 pasażerów lotu MH-17 196 miało holenderskie obywatelstwo. W swoim przemówieniu wyraził szczególne rozczarowanie wynikami dzisiejszego głosowania. Był kolejną osoba, która odwołała się do rezolucji Rady nr 2166 i przypomnial, że zakładała ona wykonanie trzech głównych kroków w związku z tą katastrofą: szybką repatriację i identyfikację ofiar, dokładne i niezależne śledztwo w sprawie przyczyn katastrofy, wreszcie sprawiedliwość dla ofiar poprzez ukaranie sprawców. Dodał ponadto, że tylko ustanowienie międzynarodowego trybunału gwarantowałoby apolityczność w tej sprawie i pozwoliłoby na wykorzystanie najbardziej skutecznego, bezstronnego i sprawiedliwego mechanizmu osądu sprawców tragedii. Wyraził niezrozumienie dla postawy Rosji, która jako członek RB tym bardziej powinna dążyć do poznania prawdy. Stwierdził, że utrzymywanie bezkarności sprawców stanowi niebezpieczny przekaz dla przyszłych potencjalnych zbrodniarzy, a także zagraża bezpieczeństwu lotnictwa cywilnego.

Na posiedzeniu nie zabrakło także Pawlo Klimkina, Ministra Spraw Zagranicznych Ukrainy, który powiedział, że ten dzień powinien zostać zapamiętany nie ze względu na weto Rosji, ale na zjednoczenie tak dużej liczby państw na rzecz zagwarantowania sprawiedliwości i przeciwdziałania bezkarności. Podkreślił, że nie ma powodu, aby sprzeciwiać się stworzeniu niezależnego trybunału, który miałby pociągnąć do odpowiedzialności winnych zbrodni, chyba, że jest się jednym z oprawców. Dodal, że rola Rosji w konflikcie na Ukrainie jest dobrze wszystkim znana, a weto jest tylko tego potwierdzeniem. Zaznaczył na koniec, że sprzeciw Rosji co prawda zablokował przyjęcie projektu rezolucji, ale i tak nie uniemożliwi poznania prawdy o tej tragedii w przyszłości.

Przemówienia wygłosili także pozostali przedstawiciele państw-autorów projektu rezolucji. W swoich wystappieniach zgodnie potępili oni zastosowanie przez Rosje weta. Dainius Baublys z Litwy stwierdził dodatkowo, że od dnia katastrofy delegacja rosyjska zachowuje się tak, jakby miała coś do ukrycia, a przez dezinformację chce wprowadzić społeczność międzynarodową w błąd. Zaznaczył, że nielegalne grupy prorosyjskich bojowników, które sprawują kontrolę nad miejscem katastrofy, zarówno tuszowały dowody w sprawie, jak i ograniczały dostęp do tego terenu międzynarodowym ekspertom oraz Organizacji Bezpieczeństwa i Współpracy w Europie (OBWE). Nie miał również wątpliwości, że zestrzelenie malezyjskiego Boeinga stanowi zagrożenie dla międzynarodowego pokoju i bezpieczeństwa. Stwierdził, że było to zamierzone działanie, a niezakłócony przepływ broni, najemników i rosyjskich wojsk na terytorium Ukrainy, suwerennego państwa, stworzył warunki do tej tragedii. Na zakończenie zaapelował o przestrzeganie umowy z Mińska oraz podkreślił kluczową rolę, jaką odgrywają OBWE i ONZ w rozwiązaniu tego konfliktu. Minister Spraw Zagranicznych Nowej Zelandii Murray McCully nie ukrywał z kolei rozczarowania brakiem jednomyślności wśród członków Rady, którym jeszcze rok wcześniej udało się osiągną́ porozumienie w sprawie przyjęcia rezolucji nr 2166. Powiedzial również, że 
nieznalezienie przez Radę odpowiedniego mechanizmu do osądzenia winnych tej tragedii zawiedzie oczekiwania rodzin i przyjaciół zmarłych. Stwierdził także, że w tej sprawie nie ma rozwiązań pośrednich i albo państwa opowiadają się za sprawiedliwością, albo za bezkarnością. Odniósł się ponadto do stosowania prawa weta w RB, mówiąc, że Nowa Zelandia jest od lat przeciwna temu rozwiązaniu i ponownie apeluje o znalezienie lepszego sposobu podejmowania decyzji w tym organie. Przedstawiciel Wielkiej Brytanii Matthew Rycroft dodał natomiast, że weto ze strony Rosji świadczy o zlekceważeniu ofiar katastrofy, a okres jednego roku od jej dnia jest odpowiednim momentem na ustanowienie trybunału i wysłanie w ten sposób czytelnego komunikatu, że Rada stanowczo sprzeciwia się aktom przemocy wobec ludności cywilnej. Julie Bishop, Minister Spraw Zagranicznych Australii zapewniła z kolei o pełnej determinacji jej kraju w dążeniu do pociagnięcia sprawców tragedii do odpowiedzialności, szczególnie, że wśród pasażerów lotu MH-17 znajdowało się 39 Australijczyków. Przedstawiciel Irlandii, Tim Mawe, podkreślił znaczenie lotnictwa cywilnego dla komunikacji globalnej i dobrobytu państw, a także wyraźnie stwierdził, że zagrożenie dla cywilnego lotnictwa jest jednocześnie zagrożeniem dla międzynarodowego pokoju i bezpieczeństwa. Reprezentant Izraela, Ron Prosor, powołal się na doświadczenia własnego kraju, mówiąc, że jeżeli nie podejmie się dzisiaj zdecydowanych kroków w celu powstrzymania aktów agresji, będzie to rodziło poważne konsekwencje w przyszłości. Przedstawiciel Niemiec, Harald Braun, zaapelował o natychmiastową i trwałą deeskalację konfliktu, a także o pełne wdrożenie porozumień z Mińska. Powiedzial również, że przykład przyjęcia rezolucji ws. irańskiego programu nuklearnego pokazuje, że jest możliwe osiagnięcie porozumienia w Radzie i jeszcze raz zachęcił jej członków do szukania konstruktywnych rozwiązań. Solidarność z partnerami i gotowość do dalszych wysiłków na rzecz osądzenia sprawców tragedii wyrazili także w swoich wystąpieniach przedstawiciele Hiszpanii, Belgii, Francji, Filipin, Indonezji oraz Kanady.

Swoje stanowiska przekazali również pozostali członkowie Rady Bezpieczeństwa oraz państwa zaproszone do debaty. Przedstawiciel Wietnamu, Nguyen Phuong Nga, podkreślił gotowość swojego państwa do ścisłej wspólpracy ze wszystkimi stronami zaangażowanymi w dochodzenie. Carlos Olguín Cigarroa z Chile dodal, że jego zdaniem wyniki głosowania obnażyły słabość Rady oraz pokazały, że nie wywiązuje się ona z odpowiedzialności, jaka na niej ciąży. Reprezentant Czadu Mahamat Zene Cherif wezwal pozostałe państwa, aby pomimo odrzucenia projektu nie zaniechały swoich wysiłków zmierzających do ukarania winnych tragedii i zadośćuczynienia rodzinom ofiar. Podkreślił również, że opowiedzenie się przez Czad za przyjęciem projektu rezolucji miało także na celu zniechęcenie wszystkich tych, którzy mogliby zagrozić bezpieczeństwu lotnictwa cywilnego w przyszlości. Na aspekt bezpieczeństwa pasażerów zwrócili również uwagę przedstawiciele Jordanii i Nigerii.

Przedstawiciel ChRL, Liu Jieyi oprócz okazania wyrazów wspólczucia dla pograżonych w żałobie rodzin i państw dotkniętych katastrofa, podkreślił, że Chiny od samego początku popierają przeprowadzenie dokładnego i niezależnego śledztwa, a także osądzenie sprawców tragedii. Swoją decyzję o nieudzieleniu poparcia dla rezolucji uzasadnił natomiast podziałami, jakie projekt ten wzbudza wśród pozostałych członków Rady. Rafael Darío Ramírez Carreño z Wenezueli także wyraził solidarność z rodzinami ofiar i ubolewał nad tragedią, natomiast uzasadniając powstrzymanie się od głosu, wyjaśnił, że powodem tego jest kontekst polityczny, jaki towarzyszy tej sprawie. Dodał również, że w toczącej się dyskusji nie należy powoływać się na rozdział VII Karty Narodów Zjednoczony, ponieważ 
katastrofa malezyjskiego samolotu nie stanowi zagrożenia dla międzynarodowego pokoju i bezpieczeństwa. Zaapelował też do innych państw o powstrzymanie się od wysuwania daleko idących wniosków na temat przyczyn i winnych tragedii, które jego zdaniem są bezpodstawne. Przedstawiciel Angoli, João Iiambeno Gimolieca podzielił zdanie swoich przedmówców w kwestii konieczności pociągnięcia do odpowiedzialności sprawców katastrofy, a uzasadniając powstrzymanie się od głosu, powołał się na rezolucję Rady z 2014 r. Stwierdził, że stwarza ona wystarczające warunki do przeprowadzenia dokładnego i niezależnego śledztwa, a ustanowienie międzynarodowego trybunału byłoby przedwczesnym krokiem.

Na zakończenie jeszcze raz głos zabrał przedstawiciel Rosji. W odpowiedzi na zarzuty, jakie pojawiły się w trakcie dyskusji wobec Federacji Rosyjskiej, wyraził niezrozumienie dla przekonania, iż dezaprobata udzielona przez Rosję wobec jednego mechanizmu zapewnienia sprawiedliwości została automatycznie utożsamiona z popieraniem przez nią bezkarności sprawców tragedii. Zwrócił się również do Ministra Spraw Zagranicznych Ukrainy z pytaniem, dlaczego rząd w Kijowie pozwolił na przelot cywilnego samolotu nad strefą konfliktu i czy ktoś na Ukrainie został w ogóle ukarany za takie zaniedbanie obowiązków. Dodał też, że posiedzenie nie ujawniło wszystkich aspektów tragedii.

Posiedzenie RB w sprawie katastrofy malezyjskiego samolotu po raz kolejny obnażyło niezdolność tego organu do wypracowania kompromisu pomiędzy jego członkami. Jest to nie pierwszy już dowód na konieczność gruntownej reformy Rady, której funkcjonowanie prawie nie zmieniło się od momentu jej powołania 70 lat temu i nie odpowiada radykalnym geopolitycznym zmianom, jakie nastąpiły na przestrzeni tych kilkudziesięciu lat. Oprócz kwestii członkostwa, metod pracy czy regionalnego przedstawicielstwa w Radzie, to właśnie stosowanie prawa weta wpływa w głównej mierze na nieefektywność tego organu. Już podczas konferencji założycielskiej ONZ w San Francisco w 1945 r. zapis dotyczący posiadania tego przywileju przez stałych członków Rady budził wiele kontrowersji. Ostatecznie zostal on podtrzymany i do dzisiaj w celu przyjęciu rezolucji, w kwestiach innych niż proceduralne, wymagane jest poparcie dziewięciu państw zasiadających w RB, w tym wszystkich pięciu stałych członków. To właśnie Rosja najczęściej korzysta z tego prawa, biorąc pod uwagę głosowania od początku działalności Rady, w tym czasy istnienia ZSRR.

\section{Tabela 1}

Liczba rezolucji zawetowanych przez stałych czlonków RB w latach 1946-2015

\begin{tabular}{|l|c|}
\hline ChRL & 9 \\
\hline Francja & 16 \\
\hline Rosja/ZSRR & 103 \\
\hline Wielka Brytania & 29 \\
\hline Stany Zjednoczone & 79 \\
\hline
\end{tabular}

Źródlo: http://research.un.org/en/docs/sc/quick (14.01.2015).

Nie należy mieć jednak złudzeń, że w najbliższej perspektywie możliwe będzie wyeliminowanie lub ograniczenie prawa weta. Aby tak się stało, niezbędne jest wprowadzenie poprawek do Karty NZ, które następnie muszą zostać zaakceptowane i ratyfikowane przez 
wszystkich stałych członków Rady. Przy istnieniu różnicy zdań na ten temat wśród samych stałych członków i ich wielokrotnej niezdolności do wypracowania porozumienia w sprawie poszczególnych rezolucji, perspektywa wprowadzenia takiej reformy wciąż pozostaje nieosiagalna.

Aleksandra GOLUS

Poznań 